Please do not remove this page

RMIT

UNIVERSITY

\title{
Whose tool for what purpose? The struggle for cultural industry infrastructure in Liberia
}

Morgan, Benjamin

https://researchrepository.rmit.edu.au/esploro/outputs/9921861076101341/filesAndLinks?institution=61RMIT_INST\&index=null

Morgan, B. (2019). Whose tool for what purpose? The struggle for cultural industry infrastructure in Liberia. In The Cultural Turn in International Aid: Impacts and Challenges for Heritage and the Creative Industries (pp. 91-108). Routledge. https://doi.org/10.4324/9781351208598

Document Version: Accepted Manuscript

Published Version: https://doi.org/10.4324/9781351208598

Repository homepage: https://researchrepository.rmit.edu.au

(C) 2020 Selection and editorial matter, Sophia Labadi; individual chapters, the contributors

Downloaded On 2023/04/27 01:01:48 +1000 
Benjamin A Morgan

Technology, Communication and Policy Lab

School of Media and Communication

RMIT University

Whose tool for what purpose? The struggle for cultural industry infrastructure in Liberia

https://doi.org/10.4324/9781351208598-6

Author/corrected version published as a chapter in:

Labadi, S. (Ed.). (2020). The Cultural Turn in International Aid. London: Routledge, https://doi.org/10.4324/9781351208598

Keywords: development studies, creative and cultural industries, Liberia, media industries, informal market, copyright 
Whose tool for what purpose? The struggle for cultural industry infrastructure in

\section{Liberia}

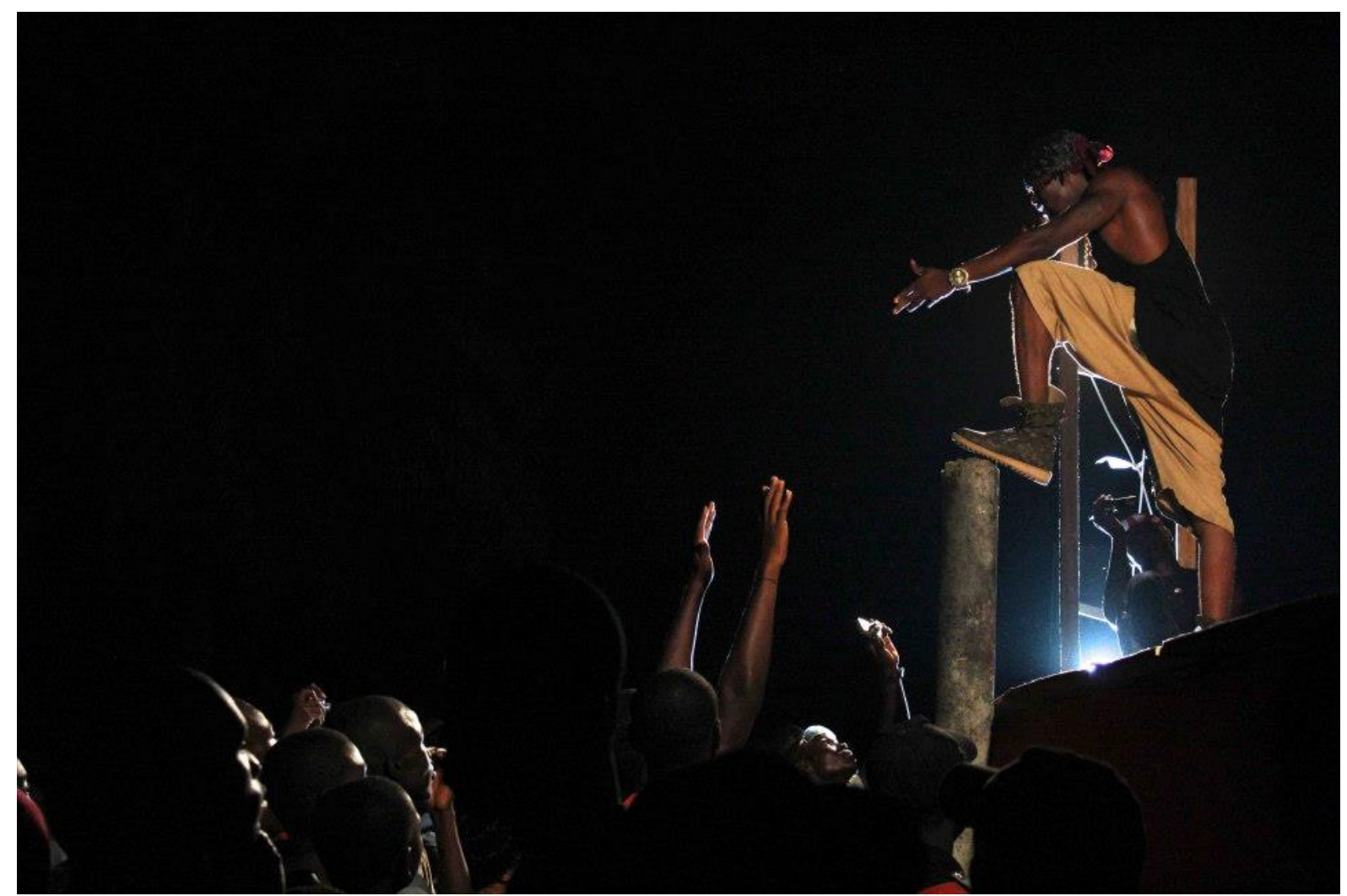

Takun J performs at the 2013 Hipco fest in Monrovia, one of the few large concert events in Liberia without an NGO, politician, or sponsor driving it. Photo by Ashoka Mukpo

In this chapter, I will reflect on my experience in Monrovia 2010-2013 as an expatriate concert promoter participating in the local music industries ${ }^{1}$ and subsequent research in 2014 as a consultant to the World Bank at a time when the sector was considered for inclusion in the country's Private Sector Development Strategy (PSDS). Using the autoethnographic method (Chang 2008; Ellis et al. 2010), I will interrogate my participant observation as a cultural outsider, privileged foreign expert and local stakeholder, and revisit the research output I produced for the World Bank. Literature from cultural policy, media industries and development studies will frame the analysis of the roles of culture ${ }^{2}$ in aid and development which I witnessed on the ground in Liberia, noting both flaws and positives. Acknowledging the discourse and institutional frameworks constraining the current path towards supporting musicians as that of the creative and cultural industries (CCIs), I reflect on why more integration of informal activity would be useful in future efforts at strategic music industry sector expansion in Liberia, rather than a punitive approach towards the informal sector. 


\section{The dream of the creative economy vs. the reality of cultural subordination}

While CCIs seemed to enjoy significant global attention as drivers of economic growth and human development in the pages of institutional reports and national policies, this optimistic Creative Economy discourse had not reached the Republic of Liberia during the years 20102013. Economic plans and humanitarian aid agendas both appeared silent in Liberia when it came to supporting CCIs. Arts and cultural sectors were not addressed in Liberia's Poverty Reduction Strategy, which was the main document that framed development projects during my time there (IMF 2008). The 2012-2013 Ministry of Information, Culture, and Tourism section of the national budget allocated 'core grants' to only two organisations: Miss Liberia Beauty Pageant and Liberia Movies Union (Republic of Liberia 2012, p. 130). The Liberian Daily Observer reported (Uncredited 2016) that President Johnson-Sirleaf did not acknowledge the creative sector in any of her annual addresses. Efforts were underway to update the country's intellectual property system as a requirement to ultimately accede to the World Intellectual Property Organization (WIPO) and the World Trade Organization (WTO) (Mengistie, Ababa \& Ouma 2009), but otherwise I saw no strategic policy or activities supporting the CCI sector. The CCIs, it seems, were not just a low priority. They were not yet invited to the discussion.

Music has an existence, meaning, and value separate from an economic role, and concentration on the economic output is only one approach to developing the arts. Advocating for investment in Liberian musicians from a non-economic, socio-cultural perspective highlighting the intrinsic value of the arts was also challenging and limiting, in particular within the human development industry. While the value and importance of arts and culture as part of a healthy community was always given lip service in conversation with other development workers, the lack of a specific cultural goal under the blueprint of the United Nations Millennium Development Goals (MDGs) made it difficult for aid industry stakeholders to advocate for arts and culture projects without either attaching them to another instrumental social change objective, or going back to framing them as economic activity and facing low-priority economic sector status. Due to this lack of support for the CCI sector as an economic priority, advocates for arts and culture found themselves tying the creative work of artists into humanitarian agendas aligned with the MDGs, framing activity in terms of measurable social impact outcomes for evaluation. Artists were often hired by humanitarian Non-Governmental Organisations (NGOs) to help spread messages through murals, 
commissioned songs, and other cultural vehicles to promote change agendas, but direct investment in building the capacity of artists to create the work they themselves desired was rare.

Upon reflection, it can be easy to see how a framework such as Creative Economy policy or a cultural goal in the MDGs was necessary to argue for government investment or NGO capacity building in a specific CCI, such as music, film, literature, theatre, etc. In the field at the time, it simply appeared that the cultural industries only had value as tools to facilitate external agendas. Without knowledge of how to engage with policy, I came to understand that attracting donor interest in the Liberian music industry sector meant embracing either the small-medium-enterprise economic development discourse and face the lack of enthusiasm for the CCIs, or embrace the instrumental, music-as-a-tool-for-social change agenda (a problematic and limiting imposition of constraints on creativity e.g. Stupples 2014).

\section{Public/private expatriate worker}

As a work of autoethnography, it is important to examine how and why I was an expatriate US citizen advocating for musicians in Liberia. I lived in Monrovia from October 2010 until June 2013, and though I was a concert promoter producing live concerts for most of this time, I also held several jobs in the NGO sector. I was hired and brought to Liberia by American friends to manage a bar/nightclub they had started with a Liberian partner. Following many years of work in the US music industries, this was an opportunity for a job abroad where I felt my expertise would be valuable, and I could experience a new musical culture. I arrived full of enthusiasm to work with the musicians of Liberia, but completely lacked any formal training or experience working in low-income countries. I expected to encounter new ways of conducting business there that I would need to learn about, but also that my expertise was a form of knowledge that Liberians artists and stakeholders lacked and desired: the roots of a normative approach.

Whether Liberian or expatriate, most people I interacted with held jobs in the non-profit humanitarian aid and development sector. Those who were in the private sector also framed their work in similar ways: business workers also spoke of helping, developing, and building capacity, while development workers held personal career goals and would talk about their need to establish relationships to secure future employment. The discourse and practices of the development sector permeated into the private sector, and as I came to hold jobs in both 
sectors, I also spoke of my work - whether for-profit or for a non-profit NGO - using a similar language. I understood my private sector work producing concerts with musicians as an effort to improve local systems and infrastructure through the discourse of capacity building. ${ }^{3}$

I believed that I was contributing to local standards, professional practice, and sharing valuable expertise as I created economic opportunities. Once I learned that many development institutions were for-profit companies (e.g. Chemonics, Development Alternatives Inc.), and that large companies engaged in corporate social responsibility (CSR) programs which resembled development interventions, the line was blurred further. While an international petroleum company (e.g. Total S.A.) has different aims than a humanitarian institution (e.g. Oxfam), I overheard constant overlap in how employees reflected verbally on the impact of their activities. While large business CSR activities were a more obvious area of discursive similarity to humanitarian projects, the managers and business owners of commercial companies spoke of training their employees as 'building capacity', and their business as helping to develop infrastructure. Combined with my background in the US popular music industries, I came to view the idea of economic interventions to stimulate cultural markets in Liberia simultaneously as human development, capacity building, and economic investment. I was quite unaware of the critical policy issues with making arts and culture subordinate to economics, and had no problems seeing the desire to support the music industries to be simultaneously an economic and cultural concern.

As noted brilliantly by Stirrat (2008), I oscillated between development worker identity stereotypes as a missionary (I was there to help Liberian musicians transform their lives), mercenary (I was there to improve my career prospects and enjoy the privileged expat lifestyle), and misfit (I could not figure out my life goals at home, so I went in search of meaning elsewhere - somewhere where I was automatically important). While I did contribute to Liberia's culture and economy, I see how some activities I engaged in were problematic and flawed. I hope that future endeavours to stimulate cultural industries might benefit from my observations. I hope to be critical through (auto)ethnography and remind policymakers of social issues outside their decision-making process (e.g. Mosse 2004), but not directly comment on the tense relationship between the academic criticism and policy impact (Schlesinger 2013). I see how the collaboration between development experts and citizens 'creates learning spaces where co-production of knowledge which can contribute to broader processes of change is possible' (Wilson 2006, p. 519). I am a practitioner-turned- 
academic offering reflective perspective on a very specific moment in policy making: approaching the development of a cultural industry in a low-income country.

\section{Foreign institutional experts who believe in the transformative power of music}

I was hired in late 2013 by an American economist working for the World Bank to draft a chapter on the Liberian music industry sector for inclusion in the Liberian PSDS. I had just left Liberia a few months prior, after three years living in Monrovia. My mandate was to 'focus on both the challenges and potential of the industry and provide a series of comprehensive interventions for sector development,' as stated in the terms of reference (World Bank 2014a). This meant describing sector deficits, advocating for the importance of the music industries, then recommending interventions to stimulate their growth. Successful inclusion of the music industry sector in the PSDS would initiate the process for allocating government funding, as well as off-budget NGO planning, to projects designed to develop the Liberian music industries by creating a policy framework for proposals within the economic development realm - where CCIs were not considered a priority. The economist who hired and supervised me was another foreign worker who enjoyed Liberian music and noted the lack of institutional support for musicians. Our work was a small scoping project to evaluate the sector, advocate for support, and see what the Government of Liberia thought.

While the Liberian PSDS was an economic plan concerned with commercial output of the private sector, we decided that arguments for social impact had to be inserted in order to warrant inclusion of the relatively small music industries as a priority. My supervisor and I were guided by personal belief in the social value and power of musical expression to positively impact society. The rhetorical 'transformative power of the arts' (Belfiore 2011) led our search for both social and economic impact to justify the relevance of the sector's inclusion as an economic priority. The terms of reference for my consultancy referenced youth empowerment, inclusion, and post-conflict peace-building as potential socio-cultural contributions of the sector, in addition to nation-branding and employment (World Bank 2014a).

We attached our policy concern to other issues which occupied more central positions in the political discourse, a perfect example of the practice of policy attachment (Belfiore 2006; Gray 2002). We fully believed, as we argued, that we would be helping the Republic of Liberia achieve economic growth and economic spill-over effects in addition to the beneficial 
social impact of more local music. This was perhaps a well-intentioned, possibly naïve attitude, worthy of critique due to its grounding in the ideology of the transformative power of music, but I maintain the belief system which motivated our work was benevolent. It is when I reflect on how we described the challenges and potential of the sector, that I now see where the project was flawed.

For readers who question whether this effort to support the Liberian music sector might have been based on more formal research into the sector and its potential vs. others, the unfortunate fact is that there was no information available on the CCI sectors in Liberia, neither formal nor informal. Our research was based primarily on my three years of participant observation and experience in Liberia as a concert promoter, and a tele-conference focus group discussion with key Liberian industry stakeholders that I had identified, held in January 2014. It is to the credit of the World Bank economist who hired me that our process was participatory and based on brainstorming sessions with stakeholders that I had worked with or identified as important, as well as my observations from my own personal interactions with artists and industry workers over the years. In retrospect, however, the research was based primarily on the input of artists, managers, and some patrons and aspiring record label owners. A particular deficit within our focus groups and my experience was the voice and perspective of the retailers. The street vendors selling music, and the warehouse distributors who supplied them with goods were notably absent, though at the time the fact that they were dealing unauthorised copies seemed to make their inclusion less important. Though I had spent years working in the sector and knew a great deal about what musicians did for money, we were ultimately cultural outsiders doing our best to advocate for the local insiders.

\section{Applying the Creative Economy discourse: The normative approach and the copyright problem}

It was through this consultancy for the World Bank that I was introduced to the UNESCO/UNDP Creative Economy Reports and economic terms such as agglomeration externalities and network spillover. ${ }^{4}$ I absorbed this new CCI economic discourse. While the PSDS chapter we submitted was still attached to social impact, the focus was the economic potential of the sector. Though it was not explicitly stated in the terms of reference, it soon became clear that describing the 'challenges and potential' of the sector meant conducting a 
gap analysis. I was encouraged to draw on my background in the US music industries when identifying gaps in the sector value chain. This seemed perfectly logical to me at the time, but it is where the trouble began. I was not aware of the theoretical concerns with such a direct comparison to the US sector, and why this normative approach could be problematic. I was unwittingly part of an attempted dialogue between the Creative Economy and the Culture in Development policy agendas: two approaches that still 'need to learn to talk to one another' (De Beukelaer \& O’Connor 2017, p. 35).

I felt qualified to analyse the Liberian music industries given my years of experience there and looked forward to writing about the sector. When it came time to recommend specific interventions, however, I became anxious. This was an opportunity to lay the groundwork for policies and programmes that could directly impact the artists and stakeholders I worked with, and I wanted to avoid the problems I knew were plaguing the global recording industry when it came to copyright. Knowing the global recording industry had been radically impacted by the emergence of digital file trading via the internet (Morris 2015; Wikstrom 2013) and realising that broadband access for Liberians would be arriving at some point in the not-too-distant future, I was wary of advocating steps towards the implementation of foreign strong IP-systems that seemed to be collapsing and re-inventing themselves back home. The imposition of strong copyright laws while trying to emulate the US market intuitively seemed like the wrong short-term approach for Liberians, though I lacked the research background to articulate specific reasons why, not to mention the 'capacity' to generate ideas for alternative approaches.

The UNDP \& UNESCO Creative Economy Report (2013) was a main source for my arguments and language. It advocated obtaining data on cultural activities and a creative approach to the informal market, but when it came to specifics on creating sustainable incomes for creators, 'the key enabling factors are the strength of infrastructure and institutional capacity to ensure that copyright laws and policies deliver the resources that communities need to foster local development' (p. 94). While it did suggest finding creative ways to integrate the informal market, it offered few examples of how this could be done. This lack of alternative approaches to copyright was unfortunate, and it was only later with exposure to scholars who have tackled the problem of intellectual property in countries where informal markets dominate (De Beukelaer 2015; Larkin 2004; Lobato 2010; Smiers 2002) that I was able to conceptualise a better approach. At the time, I was stuck with my own 
knowledge base, and the perspective that creating intellectual property and copyright infrastructure would ultimately create revenue structures.

The tension I instinctively felt was a reaction to the complex issues with imposing foreign definitions of "what "African" CCIs do and should look like' onto Liberia (De Beukelaer 2017 , p. 583). Much of this was specifically about advocating strong copyright policies that I knew would be particularly problematic for Liberia's existing informal media market, but more broadly there were problems I had not anticipated stemming from starting with a normative vision of what the Liberian music industry sector should resemble. Whether the US model specifically, or the more abstract vision of a Creative Economy, it was a fundamental flaw in our approach to begin on the premise of what the music industries should be. I was only able to fully unpack these criticisms after reflection and engagement with literature. This foreign-expertise approach is well critiqued in development studies literature (e.g. Escobar 2011) and acknowledged by most development aid workers I knew as problematic, yet imposing foreign models was still pervasive throughout development projects I observed in the field.

Unsure of how to verbalise my anxiety and conceptualise an alternative approach to the proposed method based on strengthening copyright and comparing markets, I concentrated on performing my assigned duties: I described the gaps between the Liberian and a developed (i.e. US) music industry sector, and I advocated for interventions to help the Liberian music industries more closely resemble those of my home country. By basing my recommendations on the normative ideal of my own modernist CCI lived experience, my recommendations contributed to what Linje Manyozo calls the 'spectacle of development' (Manyozo 2017): the knowledge infrastructure was simply imported from a donor country and applied to the recipient culture. Copyright reform, education, and enforcement formed the first part of our recommendations, followed by improving production and service standards through training and infrastructure, access to finance, and support for international promotion and the export of Liberian music.

\section{PSDS Strategy Negotiation Outcomes}

Our draft was delivered in March 2014, and this ended my official involvement in the effort. My supervisor at the World Bank kept me updated as revisions were made. It was relayed to me there was scepticism at the need to include the sector in the strategy as a priority. By the 
summer of 2014, an outbreak of Ebola was becoming the focus of all planning, and expat aid organisations began pulling their staff out of the country later that year. As of June 2015, it was my understanding that the music industry sector was no longer included in the PSDS strategy. I was told the chapter had been condensed and downgraded to a policy note.

Though the chapter was not included in the PSDS, stories in the Liberian press indicate that some of the strategies advocated have since come into practice. It would appear that elements of the copyright strategy are in line with government objectives (Copyright Law to be Enforced, Liberian Observer 2015) and education campaigns are underway (Forget Bureaucracy, Copyright Your Work!, Bropleh 2016). No other recommendations appear to have been implemented, though this is difficult to confirm from abroad. Before diving deeper into the reflective criticism of our work, a brief look at the state of the sector will help to clarify why some of the recommendations now concern me.

\section{Being a tool}

Most Liberian popular musicians earned income solely from performing live concerts. A few of the more popular performers described how they had been paid fees to deliver recordings to local distributors of compact discs who invested in their recording, but this practice seemed to be declining; a local example of the international trend of shrinking revenue in sales of recordings. ${ }^{5}$ As in the Global North, this drop was blamed on the ease of copying digital media. Only a minority of the artists that I worked with had produced their own recordings, and artists who had recordings were rarely selling compact discs or other physical merchandise at their performances.

The other revenue streams for performers of popular music were instrumentalised variations on the performance income: endorsement appearances for companies or politicians and work for behavioural change or awareness campaigns run by humanitarian NGOs were the main examples. During the Liberian presidential election campaign of 2011, candidates hired artists to record campaign theme songs for them, and to perform at their campaign rallies. Larger companies, particularly the local telecom providers, hired musicians as brand ambassadors and were almost always involved as sponsors of larger concerts. Artists frequently asked me if I knew of any NGOs that they could record songs for. These sorts of agenda-driven opportunities paid well and were highly sought after. An anti-rape song campaign arranged by PCI-Media Impact and UNICEF featuring hipco rapper Takun J was a 
high-quality example of a social change song campaign (Morgan 2015), and songs recorded with NGO funds that employed local artists to deliver educational messages were common, in line with the trending 'education entertainment' concept (World Bank 2014b). ${ }^{6}$

It is fair to view these social change campaigns as positive examples of locals and foreigners working together to try and solve social problems. Opportunities for artists that are primarily intended to promote a social or behavioural agenda can certainly be good for the community, but there are also issues in this cross-cultural collaboration dynamic when there is a change agenda. The instrumental use of art in international development carries substantial criticism involving power dynamics, post-colonialism, and overemphasis on the utility of art (Stupples 2014). Given highly unequal positions of power in a post-colonial context, hiring artists to create works which promote a change agenda envisioned by an international NGO is seen as a problem by those critics who are uncomfortable with international development in general. At the minimum, it should be easy to agree that hiring an artist to produce work for social messaging campaigns is certainly a constraint on the agency of the artist to produce the artwork they want to be making. Some artists and activists feel that art has a responsibility to free the people in low-income countries 'from the shackles of development both as an ideology and as a practice' (Mbembe 2009).

At the time, live concerts and instrumental opportunities seemed to be the totality of income opportunities for musicians. While instrumental opportunities were limiting and problematic, they were providing income when there was no formal market for Liberians to consume recordings in a legitimate manner. Song writing royalties, sync licensing, royalties from public performance and mechanical reproduction, broadcast fees, and other revenue sources from abstract intellectual property were concepts of which only some of the artists I spoke with were aware. Creating more intellectual property infrastructure is certainly a way forward towards better livelihoods for artists, but in our hurry to focus on what the sector should be, we overlooked much of what it already was doing well.

\section{The efficiency of telechargeurs}

Finding ways to earn money was a constant issue, but most musicians I worked with had arrangements with clubs, and were performing somewhere in town several times a week. Though artists faced low-quality opportunities when compared to more developed sectors or other countries, the market was providing them work. While detailed accounts of low or non- 
existent standards in live performance and other sectors were outlined in our PSDS valuechain gap analysis, it is far more useful to look at what did function well in Liberia, rather than what is lacking. For that, we must look at the informal distribution and sales marketplace.

The average Liberian consumer did not often have the technological means to directly copy music themselves. They were buying music from telechargeurs, ${ }^{7}$ the street vendors offering to transfer unlicensed files of song recordings onto cell phones, as well as distributors of unauthorised copies of mostly foreign physical media. Local Liberian music was difficult to find in physical formats, but the telechargeurs were distributing copies. One popular Liberian artist told me that he had encountered copies of his music for sale in unauthorised physical formats, but the main trade in local music was in digital copies on phones and laptops. The consumer pays for the music in this informal scenario, but the composer and performers are not compensated. This method of consuming unlicensed music is normalised and not widely understood as infringement. ${ }^{8}$ Whether physical copies or digital files on a phone or SIM card, the informal marketplace was extremely efficient at providing consumers with the music they desire at a price point that they could afford. No research on the level of revenue in this sector exists.

A few of the more popular Liberian artists I spoke with resented the fact that their music was being sold on the streets without revenue flowing to them, but the informal market was the only option for consumers to have access to copies of songs. The topic of using holograms or stickers to distinguish authentic copies of releases was a main topic of discussion at the 2011 Intellectual Property conference I attended. The holograms finally came into circulation in 2016 (Dopoe 2016), and this only is a stopgap measure for physical media.

The tendency to view this informal trade in recordings as criminal, parasitic, and a drain on creativity is generally a reaction influenced by the northern countries' conception of piracy of goods. Liberian musicians who were active during the pre-digital, pre-civil war era during which selling recordings was lucrative have also contributed to the narrative of the existing informal market as immoral, and called for government intervention to criminalise it (Menkor 2018). Class tension between street vendors and more elite Liberians in government is also an element to be considered. However, purchasing pirated media goods was as normal as buying coconuts. Every Liberian I was friendly with had a cell phone and was happy to let me hear their current favourite played on it. It cannot be overstated that this informal market was the only media market in Monrovia. I will now unpack the reflective criticism of our work: the 
approach to copyright policy reform, and the issues with using the US industries as the desired template for the Liberian sector.

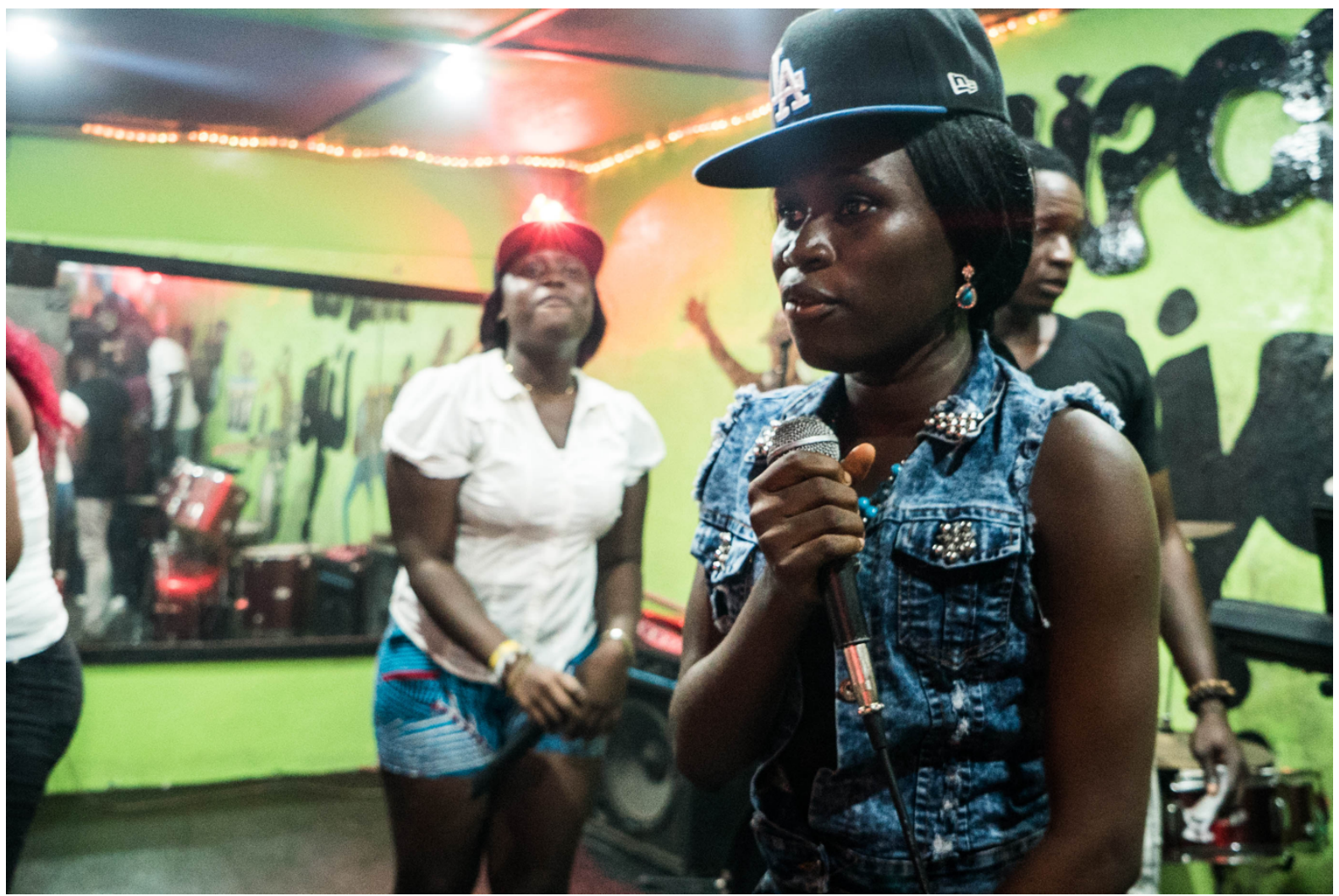

Open mic performers at 146, a small club that regularly hosts live music performances in Monrovia. Photo by Ashoka Mukpo

\section{Formalising the informal: enforcing copyright by integrating existing systems}

Given the comparatively larger scale of informality within the developing world, a global perspective inevitably requires some recalibration of policy settings and orientations. A different, indeed creative, policy approach is required for effective engagement with this [informal] sector (UNESCO and UNDP 2013, 27-28).

The Collective Society of Liberia have signed an 11-count position statement titled, 'The Monrovia Declaration', aimed at corralling and utilizing every possible resource to stop 
piracy and other infringements on intellectual property within the Republic of Liberia.

(Daily Observer 2014)

The copyright office of Liberia faces mighty challenges. They are tasked to educate the public to respect legal rights that are based on the concept of intellectual property, a relatively new concept to their culture. Their first Liberian copyright law was passed in 1997. Markets of unauthorised goods have been operating openly for decades. Vendors selling unlicensed DVDs of movies and television programmes are ubiquitous on the streets of Monrovia, including directly in front of the Ministry of Commerce where the Office of Intellectual Property was operating.

For copies of recorded media, informal vendors like the telechargeurs were the only retailers in Liberia. There were no record or video stores selling legitimate copies. There were vendors selling media out of wheelbarrows, bags, and baskets, feeding their families like any other productive member of Liberia's main marketplace - by selling goods on the street. The large distribution warehouses could be visited, but they were selling bulk product to the vendors and were not organised for retail browsing. Genuine copies of Liberian goods were supposed to carry holograms certifying their legitimacy, but I never once noticed this. I also never actually saw local Liberian content for sale on the street - counterfeit foreign copies completely dominated the market in physical goods. The street vendors carried mostly Nollywood and Hollywood films and television series. Many contained Asian language subtitles and packaging, though certainly there were distribution networks within Africa of pirated DVDs as well (Larkin 2004).

The telechargeurs and street vendors are the record store clerks of Liberia - curating collections of songs and convincing consumers to listen to certain artists. These are the purported enemies of the Liberian musicians and the copyright office - profiting from copying music illicitly. This adversarial perspective is unnecessary and detrimental. These informal vendors can be legitimised and licensed in the interim while Liberia develops formal systems, and these informal vendors are the best candidates to become a formal workforce.

While the 2013 UNESCO Creative Economy report is sensitive to the role of informal markets and advocates a collaborative approach to integrating informal systems into formal copyright structures, the problem of integrating informal markets into a legitimate copyright system is daunting and minimal specific advice is given in the report. While criminalisation 
does not always bring strict enforcement, examples of strong penalties for commercial infringement are more easily found than accounts of successful formalisation. For example, a gesture by informal cassette vendors in Ghana to the Ghanaian government in the 1980s to legitimise their unlicensed activities by paying fees to the Ghanaian performing rights organisation were squashed by lobbying from the International Federation of the Phonographic Industry (Collins 2006), and the Ghanaian copyright collection agency now sends infringers to jail for selling music from their laptop (De Beukelaer 2015). By recommending increased enforcement of copyright without a strategy for informal workers to work towards legitimacy, my policy recommendations in the PSDS chapter contributed to an anti-piracy strategy which pursues the vilification of the music sales force of Liberia. This could result in their unnecessary exclusion from future legitimate market structures.

While it might seem the recording (and film) industries typically pursue strategies to fight infringement based on prosecution or litigation, that is not always the case. It is also possible to legitimise and extract revenue from infringement, an approach I was not familiar with in 2014. Three examples where legitimate revenue was extracted from existing unlicensed activity to create formal market structures include:

1. In 2011, China's most popular website Baidu was a major source of unauthorised downloading activity. Negotiations with the world's largest record labels (Warner, Sony, and Universal) resulted in the unprecedented levy of fees onto an ISP/website for the activity it was hosting (Lee 2011).

2. Home/private recording levies on blank recordable media such as cassettes and blank CDs are collected and distributed to content creators in numerous countries, including the US, UK, Australia, and most of Europe (Wijminga et al. 2016).

3. The Nigerian film industry has been able to create a remarkably efficient worldwide distribution system and extract enough revenue from it to create a successful and influential cultural industry. While it can be difficult to understand how revenue flows back to creators, Lobato (2010) posits that this is possible when production and distribution costs remain low enough to keep prices for legitimate goods equivalent to pirated, while relying on the efficiencies of existing international informal distribution networks; goods are kept affordable and easily accessible.

Updating copyright laws and creating structures for the protection of intellectual property are necessary for the accession to the WTO, so it must be noted that this issue cannot be viewed 
in a vacuum. The livelihoods of many Liberians outside the music sector are affected by WTO membership, so intellectual property strategies are not solely about the music industries, or even just the CCIs. Ethnographic work into the relationship between local practice and copyright in countries that are developing copyright infrastructure, such as that of Larisa Mann (2011) on Jamaican music and copyright, can help to advocate for appropriate exceptions and limitations to ensure that compliance with international copyright treaties benefits both local producers and consumers as well as foreign copyright owners concerned about enforcing their rights. As both Mann (2012) and Drahos and Braithwaite (2003) note, there are structural similarities between colonialism, feudalism, and the enforcement of the IP rights of a large foreign country in a fragile economy in the Global South.

These were not concerns we considered when drafting our PSDS chapter. We assumed international media companies and other investors hoping to finance Liberia's music industries will want to see a strong copyright system and enforcement of rights before putting money into Liberian music ventures. The first priority interventions we advocated in the PSDS strategy focused on copyright education campaigns, updating copyright laws, and strengthening protection of intellectual property rights, including enforcement and confiscation of informal goods. These objectives seem to be progressing in Liberia with the passage of new copyright laws in 2016 (Republic of Liberia 2016) and the establishment of a Collective Management Organisation to provide administrative structures for royalty collection. Efforts to curtail infringement and improve legitimate systems do not need to include treating informal vendors like criminals. As of early 2018 there were no reported campaigns to confiscate goods or arrest vendors, and Liberia has a newly elected government. Aside from a power struggle over who will run the copyright office (Dopoe 2018), there have not been any notable news reports since the passage of the new copyright law.

\section{Telling them what they want}

An important question is: are vendors interested in legitimising their activity? ${ }^{9}$ Imposing this strategy to formalise their activity is irrelevant if that is not what they want. The young entrepreneurs are not likely to be registered as businesses that pay taxes and unlikely to be in a hurry to document their revenue. Legitimising them should allow them to sell more openly 
and unlock opportunities for them to take loans, expand their business, and eventually open retail stores, but what really matters is what they see as their path: the Liberian way forward. As an outsider, it is not my position to tell Liberians what their music industry should look like, and this returns us to the second major criticism of the work: using the US industries as a normative ideal and the linear approach of having a desired model. Looking at the Nigerian music industries as a better comparative model might be a good start, but ultimately Liberians must decide what sort of goals they will set and what kind of industries they wish to see.

The Liberian music industry stakeholders that I collaborated with told me frequently that they wanted international assistance and intervention. This made it easy for me to feel comfortable with my approach and to feel that I was helping, but I ought to have been focussed on what innovations were going on in the country in the informal market and seeking to build from there. Mobile broadband is where Africa's telecommunications sector is heading (Kende 2017). Like any re-organisation of a business sector, some will gain while others will lose. Music street vendors who are trained to work in the infrastructure of rights management and digital music services could benefit from this shift, whereas others might simply lose their livelihood as Liberian consumers likely migrate from physical media and local copies towards access to streaming and cloud services. It is unclear how long this shift will take $20.6 \%$ of Liberian cell phone users were using internet services in 2016 (Liberia Telecom Authority 2016). While it might be easy for Liberian musicians to look abroad and see services they would appreciate (e.g. streaming services, download stores), a realistic approach for modest and achievable growth must reflect on what (informal) practices are working in Liberia, rather than the frustrations of what does not exist or does not function correctly.

\section{Conclusion}

The comparative approach to the value-chain gap analysis that I conducted was problematic by starting from foreign normative notions of what the Liberian music industry sector should look like, rather than looking at what was already working well in the informal sector. My initial efforts in the private sector as a local stakeholder were influenced by the discourse of capacity building and human development, and this confidence in my own foreign expertise led to a failure to identify local visionaries who had innovative ideas on how to improve the sector from within. By focussing on artists and creators, we failed to include vendors, 
telechargeurs, and local entrepreneurs in our research for the PSDS strategy, a major omission. Meanwhile, the NGO community failed to contribute to developing sustainable livelihoods for musicians. Constrained by a lack of cultural industry goals in policy frameworks alongside justifying instrumental uses of the arts for their humanitarian agendas as a form of development, the constraints of the MDGs led to a reluctance to support artistic activity without attaching those efforts to social change agendas. While all these approaches are flawed and limited, they all do benefit the sector in some way. Future efforts to support CCIs in Liberia could benefit from strategic integration of existing local (informal) systems, as well as encouraging NGOs interested in working with artists to look into more projects that allow musicians to create non-instrumentalised, autonomous works.

Liberia has passed new copyright laws and joined the WTO. Looking ahead to how it will handle the existing informal market represents an opportunity to avoid repeating the results exemplified by Ghana in the 1980s when informal cassette vendors seeking a path toward legitimisation were still criminalised. The Government of Liberia can still remain WIPO compliant, increase revenue, and reduce infringement if it can take a proactive stance to negotiating terms to license and monetise informal structures, as well as make appropriate exceptions to copyright that integrate existing local practice. The vendors and telechargeurs have already created highly efficient distribution and sales systems that Liberian consumers are using. The goal can be to legitimise, monetise, and improve the existing market alongside improving and strengthening copyright systems in anticipation of an eventual shift to digital streaming services. A realistic, localised, and non-linear approach to developing the music industry sector is a better way to approach developing cultural industries in the short term than a normative comparative method focussed on copyright infrastructure. 
1 Due to a tendency to conflate the recording industry with the broader music industry sector, I prefer to use the plural music industries as much as possible. When the term music industry sector is used, it will refer to all economic opportunities for artists broadly, in particular live performance, the dominant revenue stream in Liberia.

2 I will be using a more limited definition of culture, one that is often specified by using arts and culture and implies an artist, a creative process, and an output in the form of a product or experience that normally carries symbolic meaning and is often intellectual property

3 See Eade (2007) for the problematic evolution of capacity building from its origins in the works of Paulo Freire and Amartya Sen, its popularisation by UNDP, to the use by institutions such as the World Bank in service of a 'neo-liberal agenda of rolling back the state, privatising public services (the 'marketisation' of social welfare), good governance, and democratisation' (p. 632).

4 'Agglomeration Externalities: Growth of bars/restaurants, vendors, around successful concert venues. Network Spillover: Firms gain benefits from other firms that are located nearby, such as in the clustering of music venues or record stores in particular areas' (Morgan 2014)

5 Gospel artists seemed to be an exception. Gospel CDs by Liberian artists were available. I confess to be less knowledgeable of the nuances of certain genres such as gospel and rural traditional music. Urban popular music was the area I was working in.

6 For one example of an NGO song, see Too Young to be Pregnant, commissioned by NGO Jump Liberia https://www.youtube.com/watch?v=qSWJDi1hW7o

7 For more information on telechargeurs, see Polgreen (2015).

8 At this time, the Liberian copyright law of 1997 covered infringement of copyright on physical goods, but no laws regarding digital piracy existed. New IP laws were passed in 2016.

9 We did not think to approach telechargeurs when creating PSDS focus groups, a huge oversight. We did reach out to the operators of distribution centres for physical media. They were nervous and difficult to engage. The path to legitimacy is often resisted (in many business sectors), because legitimacy means paying taxes means and sharing revenue. Either prices must be raised, or the vendors must take less money. 


\section{References}

Addy, A. M. 2015. Country Report on the Intellectual Property System, Republic of Liberia. In: 55th Series of Assemblies of WIPO Member States. Geneva, Switzerland: WIPO. www.wipo.int/edocs/mdocs/govbody/en/a_55/a_55_lr.pdf (accessed on 02/03/2018).

Belfiore, E. 2006. The Social Impacts of the Arts-Myth or Reality? In: Mirza, M. (ed.) Culture Vultures: Is UK Arts Policy Damaging the Arts? London: Policy Exchange Limited.

Belfiore, E. 2011. The 'Transformative Power' of the Arts. In: J. Sefton-Green, P. Thomson, K. Jones \& L. Bresler (eds) The Routledge International Handbook of Creative Learning. New York: Routledge.

Bropleh, T. 2016. Forget Bureaucracy, Copyright Your Work! Daily Observer, 5 May, 2016.

Chang, H. 2008. Autoethnography. Autoethnography as Method. Walnut Creek, CA: Left Coast Press.

Collins, J. 2006. Copyright, Folklore and Music Piracy in Ghana. Critical Arts, 20, pp. 158170.

De Beukelaer, C. 2015. Developing Cultural Industries: Learning from the Palimpsest of Practice. Amsterdam: European Cultural Foundation.

De Beukelaer, C. 2017. Toward an 'African' Take on the Cultural and Creative Industries? Media, Culture \& Society, 39, pp. 582-591.

De Beukelaer, C. \& O’Connor, M. J. 2017. The Creative Economy and the Development Agenda: The Use and Abuse of 'Fast Policy'. In: P. Stupples \& K. Teaiwa (eds.) Contemporary Perspectives in Art and International Development. New York: Routledge.

Dopoe, R. 2016. Liberia: Only Awareness Can Make the Copyright Law Impactful. Daily Observer, Liberia. 4 August 2016. http://allafrica.com/stories/201608040916.html (accessed on 02/03/2018).

Dopoe, R. 2018. Fight over Intellectual Property Office Leadership. Daily Observer, Liberia. 26 January 2018. www.liberianobserver.com/lib-life/fight-over-intellectual-propertyoffice-leadership/ (accessed on 02/03/2018).

Drahos, P. \& Braithwaite, J. 2003. Information Feudalism: Who Owns the Knowledge Economy? New York: New Press.

Eade, D. 2007. Capacity Building: Who Builds Whose Capacity? Development in Practice, 17, pp. 630-639. 
Ellis, C., Adams, T. E., \& Bochner, A. P. (2011). Autoethnography: An Overview. Historical Social Research / Historische Sozialforschung, $36(4$ (138)), 273-290.

Escobar, A. 2011. Encountering Development: The Making and Unmaking of the Third World. Princeton: Princeton University Press.

European Union Commission. 2010. Green Paper: Unlocking the Potential of Cultural and Creative Industries. Brussels, COM (2010). European Union Commission.

Gray, C. 2000. Local Government and the Arts. The Politics of the Arts in Britain. London: Palgrave Macmillan UK.

IMF. 2008. Liberia: Poverty Reduction Strategy Paper. International Monetary Fund. www.imf.org/en/Publications/CR/Issues/2016/12/31/Liberia-Poverty-Reduction-StrategyPaper-22145 (accessed on 02/03/2018).

Kende, M. 2017. Promoting the African Internet Economy. Internet Society. www.internetsociety.org/resources/doc/2017/africa-internet-economy/ (accessed on 01/03/2018).

Larkin, B. 2004. Degraded Images, Distorted Sounds: Nigerian Video and the Infrastructure of Piracy. Public Culture, 16, pp. 289-314.

Lee, M. 2011. Baidu in Landmark Deal with Record Labels. Reuters. www.reuters.com/article/us-baidu-music/baidu-in-landmark-deal-with-record-labelsidUSTRE76I0WN20110719 (accessed 01/03/2018).

Liberia Telecom Authority. 2016. Public Consultation Document on the Definition of Relevant Telecommunications Markets. Monrovia, Liberia: Liberia Telecommunications Authority. www.emansion.gov.lr/doc/CONSULTATION-DOCUMENT.pdf (accessed on 19/11/2017).

Lobato, R. 2010. Creative Industries and Informal Economies: Lessons from Nollywood. International Journal of Cultural Studies, 13, pp. 337-354.

Mann, L. 2011. Decolonizing Networked Technology-Learning from the Street Dance. In: S. Pager, and A. Candeub (eds.) Transnational Culture in the Internet Age. Cheltenham: Elgar.

Mann, L. K. 2012. Decolonizing Copyright Law: Learning from the Jamaican Street Dance. $\mathrm{PhD}$ in Jurisprudence and Social Policy, University of California, Berkeley.

Manyozo, L. 2017. Communicating Development with Communities, Abingdon, Oxon; New York, NY, Routledge. 
Mbembe, A. 2009. African Contemporary Art: Negotiating the Terms of Recognition. Interview with V. Pailissen. http://jhbwtc.blogspot.com.au/2009/09/african-contemporaryart-negotiating.html (accessed on 19/11/2017).

Mengistie, G., Ababa, A. \& Ouma, M. 2009. Intellectual Property Development Plan for the Republic of Liberia. Geneva: World Intellectual Property Organization.

Menkor, I. F. 2018. Liberia: Nyan Dokpa Wants Young Musicians to Fight Piracy. Daily Observer, Liberia. 2 March 2018. http://allafrica.com/stories/201803020043.html (accessed on 02/03/2018)

Morgan, B. A. 2014. Revised Draft: Development of the Liberian Music Industry. The World Bank (unpublished consultant draft report).

Morgan, B. A. 2015. Popular Music as Vehicle for Cultural Change Intervention: Takun J's Cultural Diplomacy in Post-conflict Liberia. Studia Europaea, 60(3), pp. 233-244.

Morris, J. W. 2015. Selling Digital Music, Formatting Culture. Oakland, CA: University of California Press.

Mosse, D. 2004. Cultivating Development: An Ethnography of Aid Policy and Practice. London; Ann Arbor, MI: Pluto Press.

Polgreen, L. 2015. A Music-Sharing Network for the Unconnected. New York Times Magazine. www.nytimes.com/2015/06/07/magazine/a-music-sharing-network-for-theunconnected.html (accessed on 01/03/2018).

Republic of Liberia. 2012. National Budget for Fiscal Year 2012-13. Monrovia: Republic of Liberia. www.cabrisbo.org/uploads/files/Documents/liberia_2012_approval_external_enacted_budget_ministr y_of_finance_ecowas_english_1.pdf(accessed on 01/03/2018).

Republic of Liberia. 2016. An Act to Repeal an Act Adopting a New Copyright Law of the Republic of Liberia approved July 23, 1997; and the Industrial Property Act of Liberia approved March 20, 2003, constituting Title 24 of the Liberian Code of Laws Revised, and to enact in their stead a New Title 24 to be known as the "Liberia Intellectual Property Act, 2016”. In: LEGISLATURE, L. 24. www.wipo.int/wipolex/en/details.jsp?id=16994 (accessed on 02/03/2018).

Schlesinger, P. 2013. Expertise, the Academy and the Governance of Cultural Policy. Media, Culture \& Society, 35, pp. 27-35.

Smiers, J. 2002. The Abolition of Copyrights: Better for Artists, Third World Countries and the Public Domain. In: R. Towse (ed.) Copyright in the Cultural Industries. Cheltenham: Edward Elgar Publishing. 
Stirrat, R. L. 2008. Mercenaries, Missionaries and Misfits: Representations of Development Personnel. Critique of Anthropology, 28, pp. 406-425.

Stupples, P. 2014. Creative Contributions: The Role of the Arts and the Cultural Sector in Development. Progress in Development Studies, 14, pp. 115-130.

Uncredited. 2014. Collective Society Endorses 'Monrovia Declaration' against Piracy. Liberia. Daily Observer, 21 February. www.liberianobserver.com/lib-life/collectivesociety-endorses-monrovia-declaration-against-piracy/ (accessed on 01/03/2018).

Uncredited. 2015. Copyright Law to Be Enforced. Daily Observer, Liberia. 6 August 2015. www.liberianobserver.com/lib-life/copyright-law-to-be-enforced/ (accessed on 19/11/2017).

Uncredited. 2016. Creative Sector Undermined. Daily Observer, Liberia. 4 February 2016. www.liberianobserver.com/lib-life/creative-sector-undermined/ (accessed on 02/03/2018).

UNCTAD. 2010. Creative Economy: A Feasible Development Option. United Nations Conference on Trade and Development. http://unctad.org/en/Docs/ditctab20103_en.pdf (accessed on 02/03/2018).

UNDP \& UNESCO. 2013. Creative Economy Report 2013 Special Edition: Widening Local Development Pathways. New York and Paris: United Nations Development Program/United Nations Educational, Scientific and Cultural Organization. www.unesco.org/culture/pdf/creative-economy-report-2013.pdf (accessed on 02/03/2018).

Wijminga, H., Klomp, W., van der Jagt, M. \& Poort, J. 2016. International Survey on Private Copying: Law \& Practice WIPO: Stichting de Thuiskopie. www.wipo.int/publications/en/details.jsp?id=4183 (accessed on 02/03/2018).

Wikström, P. 2013. The Music Industry: Music in the Cloud, 2nd Edition. Cambridge, UK: Polity.

Wilson, G. 2006. Beyond the Technocrat? The Professional Expert in Development Practice. Development and Change, 37(3), pp. 501-523.

World Bank. 2014a. RE: Terms of Reference: Liberia Private Sector Development Strategy (PSDS) Music Industry Value Chain. Type to Morgan, B. Unpublished document. World Bank. 2014b. World Development Report 2015: Mind, Society, and Behavior. https://elibrary.worldbank.org/doi/abs/10.1596/978-1-4648-0342-0 (accessed on 02/03/2018).

Yuidice, G. 2003. The Expediency of Culture: Uses of Culture in the Global Era. Durham: Duke University Press. 